\title{
INTEGRATION OF PSYCHOLOGICAL AND PHILOSOPHICAL CONCEPTS M. BEKSULTANOVA IN HUMANISTIC FUNCTIONS
}

\author{
R. Tataeva ${ }^{1}$
}

DOI: http://doi.org/10.15350/L_27/03

\section{Abstract}

This paper analyzes the issues devoted to psychological and philosophical concepts of art M. Beksultanova. Are given the fundamentals and concepts of contemplation, possible to expropriate the psychology of art and humanistic aesthetics.

Keywords: artistic creativity, integration, art, psychology, message of interpretation, didactic humanism, psychological and philosophical aspect.

От колоса должно зерно родиться, от человека - свет его добра...

Иван Минтяк

Обозначая доминантные тенденции чеченской митературы XX века, её значение в историческом процессе, учёные предлагают интеграцию монолитных фигур, созданных принятой порубежной периодизацией, способствующей потенциальному приятию художественно-философских концепций мира и человека. Осуществляя предложенные аргументы цельности, необходимо: концентрировать характеристику комплекса "реализмов" опредеценных ужасом тоталитаризма; изобразить имманентную гибкость модернизма (эволюция символизма к акмеизму, формирование футуризма); предоставить беспристрастную картину противоречий и пафос созидания. Подобный концепт ценностей искусства обусловливает гипотезу о типологии творческих индивидуальностей и дифференциацию "таланта и гениальности художественного созерцания" [1, С. 85]. В целом, аксиология трудов писателей Чечни обусловленная мемуарными оттенками, авто-

\footnotetext{
${ }^{1}$ Rovzan Tataeva, Chechen State Pedagogical University, Russia.
} 
биографией, фрагментами хронологии, митературной иконографией и трагической фатальностью бытия, продолжена М. Бексултановым и "товарищами по цеху".

Объединенные эстетическим сознанием и этнографической атмосферой, произведения Бексултанова фундаментальный потенциал интегрирования и амальгамирования границ гетерогенных интерпретаций, соответствующий знаковой системе и эмементам архифакта. Исповедальные мотивы, определяющие рубежное преломление, означены в его сборниках «Мархийн кІайн гІаргІулеш" ("Облаков журавли белые») - 1985г.; "Юха кханна а селхана санна" (ИИ снова завтра, как вчера») - 1988г.; "Наггахь сайн сагатделча" ("Иногда, когда мне грустно"); "Я хьан тухур хьа неІ" ("И кто постучится в твою дверь") - 2004г.; "Сан вешин тІехьийза йоI" ("Девушка моего брата") - 2011г.

Медитативно интегрируя психолого-философские идеи в гуманистической функции, помогающие индивиду адаптироваться в критических условиях сакральным позитивизмом, писатель творит: “... из подиинного созерцания, недоступного по своей энергии чистоте или глубине его современникам" [2, С.274]. Значит, наблюдение допустимо-используемо в психологии искусства, что отмечено в работе "Одинокий художник" И.А ИАьина: "... тонкому и художественно зоркому психологу предстоит обширное и упоительное поле для исследования; и работа его даст бесконечно много и психологии творчества, и эстетике, и художественной критике, и творящим художникам, и воспринимающим обывате-

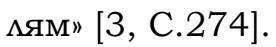

Уникальность Бексултанова, характеризуется медитациями о форме существования, верованиях, нивелированием "биографии души" в периодической фрагментарности, овмадением универсальным методом раскрытия индивидуума, т.е. созданием психологического портрета в интерьере времени, зараженного "пестрой маргинальностью" - основным недугом цивилизаций. Дефиницируя генезис религии и культуру этночеченцев, он соотносит: адаты и Коранические страницы, мифы и трагедии исторической героизации; раскрывает целостную константу социумов во временном пространстве. Направляя сенсуальность Аниме (душе), а не Разуму (рассудку), усилил изображение атомизированных артефактов, губительно вмияющих на будущее.

Данный аспект дидактического гуманизма, научно обосновывают возможности эмансипации и перспективного регресса 
Аичности; синтезируют регулятивную, семиотическую, социальнопсихологическую меру, аргументированную известным хирургом - кибернетиком Н.М. Амосовым в книге "Мысли и сердце». Аналогичная экспозиция бексултановских вопросов и доводов дополнена атомизированными вкраплениями гуманистических граней. Иначе, планомерность тематики, сюжета и композиции повестей, явцяется средством ретроспективного анализа действительности при абсолютном пассеизме автора. В частности, рассказ «Кхуна иза цахиънера" ("Он этого не веда^”) повествует о супружеской паре преклонного возраста, с "мягким консерватизмом». Основанием генерации образов послужиц ценный источник - принцип контраста поколений, достигнутый когнитивным стилем (диалог и монолог), определивший духовное целомудрие стариков.

Созидательная динамика, выраженная фееричными сегментами (фольклор, изысканные обороты речи - шутливая перебранка и воспоминания о прошлом героев), отражают менталитет и субъективное видение этнотрадиции повествователя. Вопреки устойчивому представлению о гармонии поколений в традицион-

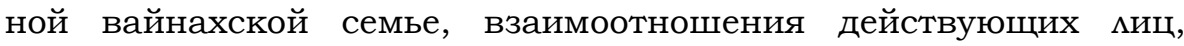
определяется внутренней напряженностью, перешедшей в откровенную апемляцию. Родителей тяготит дегенерация внутрисемейного этикета, аморальная бестактность детей, безвестность:

- Къарибат, алахь... ала мегар дацар-те...

- Оьзда ма дац иза, ва Атаби, муха эр ду ас, йоІан-йоI хима а там болчу... [4, С.336].

- Цхана кхечуьнга...

- Нахе хума муха олу..." [5, С. 337].

- Къарибат, ответь... Может сказать...

- Это же неприлично, ну, Атаби, как, как я скажу подобное..., почти ровеснице внучки....

- А через кого-то...

- Как можно через посторонних....

Кумьминация конфликта возникает с возмущения и антипатичного удивления свекра поведением невестки и сына. Трагическая уникальность ситуации заключается в ожидании стариков внимания со стороны детей через внука. Несоизмеримость страданий родителей усимено мишением их мечты - внука. Прежде всего, это "эффект обманутого ожидания", ввергнувший героев в апогей: "...Воккха стаг букь кагбелча санна, висира... Ц1е уьдура пхенашкхула. Б1аьрса дайра...” [6, С.340]. ("...Старика парализо- 
вало, словно перелом спины... Жар бегал по венам. Свет в очах потух").

Сюжетно, писатемь поражает, потрясающей пустотой в семье, что охватывает страх спровоцированный вечным конфликтом поколений. Х.Ортега-и-Гассет подчеркивац, что “... главное в жизни поколений отнюдь не то, что они сменяют друг друга, гмавное - их взаимопересечение, перехлест" [7, С.274].

Художник не рисует картин борьбы, она на психологическом уровне, в ремарках родителей - Атаби, Къарибат, а также в эпизодически-сепаратном существовании детей, пренебрегших в угоду эфемерностям бытия мировоззренческой схемой и нравственностью, что непостижимо старшим поколением: "...Цунна цахаьара, хІара х1ун ду, х1унда ду, хІара мичара ду, маца ду. Цунна зуда, бераш а деш, керт а мелош, шен доьзам а, цІийнада а 1алашвеш, яха еза моьттинера. Моьттинера боьрша стаг доьзална напагІа а мохуш. уьш шийла а, меца а ца буьтуш. уьш оьзда, гІилмакхехь кхиа а беш, ваха веза. Кхунна моьтург кхуьнцанний кьандемла химлера, тишдемла дІадаьмла. Кхунна иза ца хиънера" [8, С.340]. ("...Он не знал, что это, почему, откуда это, с каких пор. Он думал, что предназначение женщины - это быть заботмивой женой и матерью, хорошей хозяйкой. Думал, что мужчина обязан обеспечить семью. Оберегая семью от голода, холода, обязан воспитать их приличными и порядочными мюдьми. Его мнение с ним же и состарияось, обветшало, исчезцо. Но он этого не знал. Не ведам ...").

Проблемы иццюзорного восприятия молодым поколением мира, требующего жертв, перекликаются с басней И. Крымова "Оракум":

В каком-то капище быц деревянный бог,

И стал он говорить пророчески ответы

И мудрые давать советы.

За то, от головы до ног

Обвешан и серебром и зматом,

Стоял в наряде пребогатом,

Завален жертвами, момьбами заглушен

И фимиамом задушен...

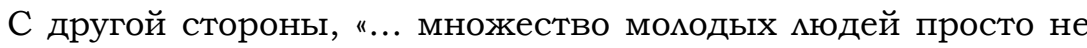
представляют, как можно строить планы на будущее, думать о завтрашнем дне... Дия них все в значительной мере мимолетно, преходяще, поверхностно" [9, С. 54]. 
Сторонник исторически сложившихся патриархальных позиций о семье М. Бексултанов остро переживает трагедию героев: отчужденное одиночество стариков, рецессию преемственности, гипертрофический нигилизм, неопытной молодежи. Это тревога за самоуничижительное поколение, утопающее в пороках, а главное гибнущую породу нации.... Он заинтересован в этнологической адаптации читателя в обозначенной концептуальности, оставшейся дмя читателя туманной.... Проблема преемственности поколений в творчестве автора перманентна, что обусловлено, рокировкой их имманентности и трансцендентности.

Рассказ М. Бексултанова "Кхуна иза цахиънера" ("Он этого не ведал") это месседж современника - современнику о распиате: "... конфликт поколений - универсальный мотив истории. Он базируется на изначальных чертах человеческой натуры... Эта борьба продолжается непрерывно, то скрыто, то явно; она никогда не кончается явным триумфом молодых, ибо к тому времени, когда они побеждали, они уже становились мюдьми средних мет" [10, P. 32].

В целом "краеугольная философия" и неиссякаемая эстетическая концепция Бексултанова, воплощенные в художественных образах произведений обусловлены - динамичностью гуманистических тенденций и антропоцентризмом. Именно гуманистические традиции в творчестве писателя позволяют иначе взглянуть на морально-нравственные аспекты современников, смысл их бытования.... Проблема обретения смысла в условиях кризиса ценностей и авторитетов - одна из социальных проблем, содержащая в себе вызов гуманистической психологии.

\section{References}

[1] Агапов Д.А. Психолого-культурологическая концепция созерцания в работах И.А. ИАьина. Научный журнал "Известия Самарского научного центра РАН" 2009. том 11, № 4. С. 85.

[2] ИАьин И.А. Одинокий художник...: ИАьин И.А. Одинокий художник. Статьи, речи, комментарии. М., Искусство, 1993. С. 273-274.

[3] Там же. С. 274

[4] Бексултанов Муса. Гулйина проза.1-ра том. Я хьн тухур буьйсанна хьан неl... Дийцарш. Соьмжа-гlasа, "ДОШ" издательство, 2005 шо. 736c. C. 336.

[5] Там же C. 337.

[6] Там же С.340.

[7] Ортега-и-Гассет Х. Вокруг Галимея // Он же. Избранные труды. М., 1997. C. 274

[8] Бексултанов Муса. Гулйина проза.1-ра том. Я хьн тухур буьйсанна 
хьан неl... Дийцарш. Соьмжа-гla八а, “ДОШ” издательство, 2005 шо. 736c. С. 336. С.340.

[9] Бобылев С.Н. "Доклад о развитии человеческого потенциала в Российской федерации 2009" М.: Весь мир, 2010. С. 54.

[10] Feuer L.S. The Conflict of Generations. The Character and Significance of Student Movement. NY, 1969. P. 527-528. 14.Ibid. P. 32. 